\title{
Monetary and Fiscal Policy Interactions in Brazil: An Application of The Fiscal Theory of The Price Level
}

\author{
Marcelo Ladeira Fialho \\ Marcelo Savino Portugal
}

Graduate Student, Universidade Federal do Rio Grande do Sul - UFRGS

Professor of Economics at Universidade Federal do Rio Grande do Sul (UFRGS), and associate researcher of CNPq

\section{RESUMO}

O objetivo do presente artigo é verificar a existência de um regime de dominância monetária ou fiscal no Brasil no período pós-Plano Real. A análise é baseada em um modelo proposto por Canzoneri, Cumby e Diba (2000). O procedimento modela relação entre as séries de dívida publica/PIB e superávit primário/PIB usando um do vetor auto-regressivo (VAR) e analisa as funções de impulso-resposta. Um outro objetivo é a extensão do artigo escrito por Muscatelli et al. (2002) sobre as interações entre políticas monetária e fiscal, usando agora o modelo do vetor auto-regressivo com mudanças de markov (MS-VAR) introduzido por Krolzig (1997), uma vez que a relação entre essas políticas pode não ser constante ao longo do tempo. A conclusão mostra que a coordenação macroeconômica entre políticas monetária e fiscal no Brasil foi virtualmente uma política substituta durante o período estudado, com um regime monetário predominante em oposição às políticas não-ricardianas da Teoria Fiscal do Nível de Preços.

\section{PALAVRAS-CHAVE}

teoria fiscal do nível de preços, VAR, MS-VAR, política monetária, política fiscal

The aim of the present paper is to verify the predominance of a monetary or fiscal dominance regime in

Brazil in the post-Real period. The analysis is based on a model proposed by Canzoneri, Cumby and Diba (2000). This model proposes that there is a relationship between the public debt/GDP and primary surplus/GDP series by using the vector autoregression (VAR) framework and analyzing the impulse response functions. Another aim is the extension of the article written by Muscatelli et al. (2002) about the interactions between monetary and fiscal policies using the Markov-switching vector autoregressive model (MS-VAR) introduced by Krolzig (1997), since the relationship between these policies may not be constant over time. In conclusion, the macroeconomic coordination between monetary and fiscal policies in Brazil was virtually a substitute policy throughout the study period, with a predominantly monetary regime, in opposition to the non-Ricardian policies of the Fiscal Theory of The Price Level.

KEY WORDS

fiscal theory of the price level, VAR, MS-VAR, monetary policy, fiscal policy

JEL Classification

E63, E3I 


\section{INTRODUCTION}

It is common knowledge that the relationship between monetary and fiscal policies is widely debated in the macroeconomic literature and broadly discussed on a worldwide basis. In this regard, fiscal policy may affect the successful outcome of monetary policy in varied ways: by way of its impact on the credibility of monetary policy, via shortterm effects on demand, and through changes in the long-term conditions of economic growth and inflation. Traditional studies deal with the interactions between policies as a perfect combination between them when both political instruments are controlled by a single policymaker. In recent years, the analysis has been changed in order to sort out the powers of fiscal authorities and of an independent Central Bank. Some studies have analyzed the interactions between monetary and fiscal policies when the policymaker's aims are not the same. An important issue concerns whether fiscal discretion should be seen as a threat to monetary commitment. Moreover, the economic theory sets three objectives based on this interaction between policies: high employment rate, price stability and quick growth. However, there is some controversy in the economic literature over the achievement of these aims.

The fiscal theory of the price level (FTPL) rests on the assumption that price stability is unattainable unless government intertemporal solvency is guaranteed. This implies that a rise in inflationary pressure calls for an increase in interest rates and for the sterilization of high debt service payments.

The principles of this theory have been re-examined by the recent literature. According to this view, it is necessary to have an appropriate monetary policy and also an adequate monetary policy in order to achieve price stability. Unless specific measures are taken to assure an appropriate fiscal policy, the objective of price stability may not be attained despite the commitment and independence of the Central Bank. This theory implies that Central Banks concerned with price stability have to do more than just maintain monetary policy unchanged, they also have to convince fiscal authorities to adopt an appropriate fiscal policy.

Some studies have been undertaken in order to explain the price level. Canzoneri, Cumby and Diba $(2000)^{1}$ used a bivariate vector autoregressive system to check the existence of a Ricardian regime in the United States in the 1951-1995 period. According to these authors, a regime in which primary surpluses are determined indepen-

1 In this regard, Debrun and Wyplosz (1999) and Mélitz (2000) estimated the reaction functions for twelve European Union and OCDE countries in order to assess whether primary surpluses respond positively to the level of debt. The obtained results showed that there is a statistically significant positive relationship between public debt and primary surplus, which makes it impossible to conclude that governments do not take into account their respective intertemporal budget constraints. In other words, a fiscal policy may have been implemented based on a Ricardian regime, and therefore, these results cannot validate the FTPL. 
dently of the level of debt such that money supply and price level satisfy the government's fiscal obligations is called a fiscal dominance (FD) regime. On the other hand, if primary surpluses respond to the level of debt in such a way that they guarantee the government's fiscal solvency, then money stock and price level may be determined by money supply and demand, which characterizes a monetary dominance (MD) regime. At the heart of the matter is whether fiscal or monetary policies provide a nominal anchor for the economy.

Semmler and Zhang (2003) analyzed the interaction over time between monetary and fiscal policies in France and in Germany in the 70s, 80s and 90s. They applied a state space model with Markov switching to estimate the time-varying vector of parameters of a simple model. Thus, the aim was to check whether there were regime shifts in the interactions between monetary and fiscal policies, and if so, how this occurred.

Since the relationship between monetary and fiscal policies is a key factor for price determination, it is worth mentioning some empirical studies that deal with this issue: Mélitz (1997), van Aarle et al. (2001), Muscatelli et al. (2002), Smaghi and Casini (2000).

We can also cite some empirical studies that deal with monetary or fiscal dominance regimes in the Brazilian economy, such as: Pastore (1995), Rocha (1996, 1997), Luporini (2001), Tanner and Ramos (2000) and da Silva and Rocha (2003).

Therefore, considering the relevance of issues such as inflation and public debt in the recent Brazilian economic scenario, as well as the advent of the fiscal theory of the price level (FTPL) as an alternative method to the elucidation of price level determination, it is important to study the application of this theory to the Brazilian economy in the post-Real period. In this sense, the fundamental aim of the present paper is to check whether the price level in the Brazilian economy is determined by the channels of conventional monetary theory or by those proposed by the FTPL.

The paper is organized as follows. Section 1 shows the first theoretical models concerned with the fiscal theory of the price level and with the interaction between monetary and fiscal policies. Section 2 presents the econometric models to be estimated. Specifically, the analysis is based on vector autoregressive (VAR) models, using impulse response functions to check the possible relationship between public debt/GDP, primary surplus/GDP and the behavior of interest rates over time, and on Markov switching vector autoregressive (MS-VAR) models, to verify how monetary and fiscal policies are conducted and which monetary dominance regime (where primary surpluses respond to the level of debt so as to guarantee the government's fiscal solvency, then, money stock and price level may be determined by money supply and demand), or fiscal do- 
minance regime (in which primary surpluses are determined independently of the level of debt such that money supply and price level satisfy the government's fiscal obligations) is determined in Brazil. Last but not least, the last section presents the estimations obtained from the models and our concluding remarks.

\section{MAJOR THEORETICAL DEVELOPMENTS}

The traditional function of a Central Bank is to control the price level. Since Fisher's work (1911) nearly all economic studies on price determination have been based upon the quantity theory of money. Nevertheless, contrary to the "monetarist view", there is a new approach, the FTPL (fiscal theory of the price level), which establishes that price determination is a fiscal phenomenon instead of a monetary one.

The FTPL and the quantity theory of money, despite their apparent discrepancies, are not mutually exclusive theories but different aspects of the same theory. Economic models concerned with these issues differ as to the way they deal with the coordination of economic policy by using the following equations, which include two equilibrium conditions involving the price level:

$$
\begin{aligned}
& M_{t} v=P_{t} y \\
& \frac{B_{t-1}}{P_{t}}=\mathrm{E}_{t} \sum_{j=0}^{\infty} m_{t, t+j} S_{t+j}^{*}
\end{aligned}
$$

where $M_{t}=$ nominal money supply, $Y=$ income, $B_{t-1}=$ nominal value of bonds, $m_{t, t+j}=$ discount factor and $S_{t}^{*}=$ government's surplus, including seigniorage.

The first equation represents a money demand function. The second equation usually stands for the government's intertemporal budget constraint. This way, the government determines the debt, money supply, and surplus, $\left\{B_{t}, M_{t}, s_{t}\right\}$. The problem is immediately noted: (1) and (2) are two equations for one unknown variable, $p_{t}$. Therefore, fiscal $(B, s)$ and monetary $(M)$ policies have to be coordinated in order to determine a single price level, given that any equilibrium requires that (1) and (2) be respected, the equilibrium is only defined for a restricted set of $\left\{B_{t}, M_{t}, s_{t}\right\}$.

It is also useful to consider that the monetary authority controls money supply $\left\{M_{t}\right\}$ and that the fiscal authority controls $\left\{s_{t}, B_{t}\right\}$. Sargent (1987) describes this situation as a "game of chicken" between the Central Bank and the Brazilian Treasury Department. However, this view may be misleading. What actually matters in the end is to know 
whether the government generated a sequence $\left\{B_{t}, M_{t}, s_{t}\right\}$ that results in a single and positive price level sequence $\left\{p_{t}\right\}$ that simultaneously solves (1) and (2).

It is therefore worth specifying some special cases or regimes that show this coordination. The standard "monetarist view" provides a simple answer to the question about the achievement of price stability. All that is required is that the Central Bank be committed towards such policy. This doctrine recognizes that both fiscal and monetary policies have to be properly selected in order for an economy with stable prices to exist. And if the Central Bank is committed towards its objective, this would automatically force fiscal authorities to adopt an appropriate fiscal policy.

Thus, according to the "monetarist view", the Central Bank determines $\left\{M_{t}\right\}$, and thus defines the price level $\left\{p_{t}\right\}$ through equation (1). The fiscal authority then adjusts the surplus, choosing the sequence $\left\{s_{t}\right\}$ such that equation (2) is defined no matter the price level determined in (1) and no matter the choice of $\left\{M_{t}\right\}$ made by the monetary authority.

Many monetarist analyses start and finish in $M v=p Y$ without introducing equation (2). Such omission is revealing. The price level has already been determined and the surplus is just one among many other less interesting endogenous variables. However, a complete quantity theory has to include a fiscal value equation as (2) and a specification of fiscal policy that is consistent with the monetary policy.

The so-called Sargent and Wallace's (1981) unpleasant monetarist arithmetic analyzes a fiscal regime in which the Central Bank still has some control over the behavior of inflation. By expressing the total surplus $\left(s_{t}^{*}\right)$ as its fiscal component (taxes minus expenditures) $s_{t}$ plus seigniorage, equation (2) can be rewritten as:

$$
\frac{B_{t-1}}{p_{t}}=\mathrm{E}_{t} \sum_{j=0}^{\infty} m_{t, t+j}\left[s_{t+j}+\frac{M_{t+1}-M_{t+j-1}}{p_{t+j}}\right]
$$

This fiscal regime assumes that the Brazilian Treasury Department compensates for any seigniorage, controlling all surplus $s_{t}$ regardless of Central Bank measures, or (in practice) that the amount of seigniorage is so small that it could be disregarded. In Sargent and Wallace's fiscal regime, the Treasury Department controls the primary surplus, setting $\left\{s_{t}\right\}$, but it does not control or compensate for the seigniorage component of the surplus. Therefore, the Central Bank has some control over the behavior of prices; it may choose between "inflation now" and "inflation later" based on its selection of 
$\left\{M_{t}\right\}$. If a low $M$ is chosen today, $p_{t}$ will be reduced and the real value of debt $b_{t-1} / p_{t}$. will be increased. However, now the Central Bank alone has to generate a coordinated policy. It has to increase $\left\{M_{t+j}-M_{t+j-1}\right\}$ in order to increase seigniorage at a later date such that (2) is satisfied at today's low price level. This measure will result in a higher inflation in the future.

The line between monetary and fiscal regimes does not have to be defined in detail. Many monetary analyses implicitly specify that in "normal times" the fiscal authority will be passive by gradually adjusting surpluses in small amounts to compensate for small changes in the government's debt value brought about by slight changes in monetary policy. Nevertheless, in bad periods, fiscal needs may be greater than those which the Treasury Department can or will satisfy. Then, the fiscal regime becomes dominant and currency collapses or causes hyperinflation.

From the fiscal standpoint, the fiscal authority wins the "game of chicken". If the Brazilian Treasury Department sets $\left\{s_{t}\right\}$ and $\left\{B_{t}\right\}$ then the government's value equation (2) determines the price level. The Central Bank then follows a passive policy by determining $M_{t}=p_{t} y / v$. The demand equation now determines the amount of money instead of defining the price level. This shows how an equation, the government's intertemporal budget constraint, can be used to determine prices. Thus, the price level is attained due to fiscal decisions. These fiscal decisions result in a real surplus $\left\{s_{t}\right\}$ that represents the government's current availability to pay public security holders. If the nominal value of the debt is $\left\{B_{t}\right\}$, the natural definition of price level is $P=B / s$.

Leeper (1991), Sims (1994) and Woodford (1994, 1995, 1996, 1998, 1999) draw some attention to models in which the Central Bank follows the rules of nominal interest rates. Although this kind of rule may originate from the lack of price level determination, the fiscal anchor may actually lead to a determined price level even with such policies.

This can be observed in equations (1) and (2). Uncertainty is initially admitted. If the Central Bank uses a nominal interest rate target and if the real interest rate is set in $r$, then an interest rate target means that the Central Bank follows any $\left\{M_{t}\right\}$ to generate a constant inflation rate, $p_{t+1} / p_{t}=\pi$. For a given initial price level $p_{0}$, the Central Bank follows $M_{t}=y p_{0} \pi_{t} / v$ and we obtain $p_{t}=p_{0} \pi_{t}$.

If the Brazilian Treasury Department is passive as occurs in monetarist tradition, this description of the policy does not determine $p_{0}$, and then the price level is left undetermined at any date. However, if the Treasury Department does not follow a passive policy, the initial price level may be identified by the government's value equation (2), and price level determination is then restored. 
This example, albeit simple, may be misleading, suggesting some discrepancy between the "initial period" and the subsequent periods. This apparent difference is purely the result of a perfect foresight model. In a stochastic model, every day is the "initial period", such that every price sequence is not identified by the interest rate rule. Specifically, a target nominal interest rate is now an expected inflation target. The Central Bank chooses $\left\{M_{t}\right\}$ to obtain $\pi=E_{t}\left(p_{t+1} / p_{t}\right)$. Money and prices follow random walks and $p_{t+1} / p_{t}=\pi+e_{t+1}$. With a passive fiscal policy, money supply does not determine the price level and monetary shocks $e_{t+1}$, and then all the behavior of the price level is undetermined. ${ }^{2}$ On the other hand, an active fiscal policy and government's value equation (2) identify the shock to the price level at each date.

\section{METHODOLOGY}

This section presents the methodology used in the present study to explain how these tools are useful to achieve satisfactory results based on the available literature. Section 3 shows the main models used for later empirical analysis: VAR and especially MS-VAR models, whose application is quite recent in the literature. What is interesting about this approach is that it may point to better conclusions than other methodologies.

\subsection{Empirical Model}

Given the interest in testing the application of the FTPL to the Brazilian economy, our aim is to confirm the existence of a systematic relationship between public debt/GDP $\left(W_{t}\right)$ and primary surplus/GDP $\left(S_{t}\right)$. According to Canzoneri, Cumby and Diba (2000), a VAR model is estimated for these two variables so as to check the empirical evidence of a fiscal dominance or monetary dominance regime in Brazil. Alternatively to this model, the publicdebt/GDP $\left(W_{t}\right)$ variable may be replaced with real interest payments $\left(R I P_{t}\right)$, where $R I P=$ operational deficit - primary deficit, according to Tanner and Ramos (2000).

In addition to the VAR estimation, an MS-VAR model is also proposed, ${ }^{3}$ among the government's policy instruments, such as basic interest rate - SELIC $\left(R_{t}\right)$ - and primary surplus/GDP $\left(S_{t}\right)$. Thus, we will verify whether there are regime shifts in the interactions between monetary and fiscal policies in Brazil in the post-Real period, and if

2 Cochrane (2000) goes further by stating that price level may be determined even in the absence of money demand. The author also shows that this determination is possible even if $v=\infty$ or if equation ( 1 ) is simply eliminated. In this model, given $\left\{S_{t}, B_{t}\right\}$, equation (2) alone can determine the price level.

3 See Krolzig (1997). 
so, how this occurs. The difference regarding this model is that Markov switching is assumed in the variance of shocks.

\subsubsection{Vector Autoregressive (VAR) Models}

The major characteristic of VAR models is the treatment, with no a priori distinction between endogenous and exogenous variables. The forecasts obtained through this method are in many cases better than the ones obtained from the most complex simultaneous equation models.

The major practical challenge in VAR estimation is to choose the appropriate lag length. If we have a model of $m$ equations with $p$ lagged values of $m$ variables, we have to estimate a total of $\left(m+\mathrm{pm}^{2}\right)$ parameters. Unless the sample size is large, the estimation of so many parameters will require many degrees of freedom.

$A \operatorname{VAR}(p)$ process considers a column vector with different $k$ variables, $y_{t}=\left[y_{1 t} y_{2 t} \ldots\right.$ $\left.y_{k t}\right]$ and models it in terms of its past values:

$$
Y_{t}=m+a_{1} y_{t-1}+a_{2} y_{t-2}+\ldots+a_{p} y_{t-p}+\varepsilon_{t}
$$

$a_{i}$ are $k x k$ coefficient matrices, $m$ is a vector of constants with dimension $k x 1$ and $\varepsilon_{t}$ is a vector white noise process, with the following properties:

$$
E\left(\varepsilon_{t}\right)=0 \text { for all } t \quad E\left(\varepsilon_{t} \varepsilon_{s}^{\prime}\right)=\Omega \text { if s=t and } 0 \text { if } s \neq t
$$

where we assume that the covariance matrix $\Omega$ is defined as positive. Thus, $\mathcal{E}^{\prime} s$ are not serially correlated, but may be time correlated.

In a two-variable system there may be a sequence $\left\{S_{t}\right\}$, in our case primary surplus/ GDP, being affected by current and past values of another variable $\left\{W_{t}\right\}$, public debt/ GDP, which is also affected now by current and past values of variable $\left\{S_{t}\right\}$. Thus we have a bivariate system as

$$
\begin{aligned}
& S_{t}=b_{10}-b_{12} W_{t}+\gamma_{11} S_{t-1}+\gamma_{12} W_{t-1}+\varepsilon_{S t} \\
& W_{t}=b_{20}-b_{21} S_{t}+\gamma_{21} S_{t-1}+\gamma_{22} W_{t-1}+\varepsilon_{W t}
\end{aligned}
$$


Where it is assumed that: 1) both variables are stationary; ${ }^{4}$ 2) $\varepsilon_{S t}$ and $\varepsilon_{W t}$ are white noise disturbances with standard deviations $\sigma_{S}$ and $\left.\sigma_{W} ; 3\right) \varepsilon_{S t}$ and $\varepsilon_{W t}$ are uncorrelated.

Equations (5) and (6) constitute a first-order autoregressive vector (VAR) with the size of the largest lag equal to one. The structure of this system includes the restoration of $S_{t}$ and $W_{t}$ affecting one another. For instance, $-b_{12}$ is the contemporaneous effect of the change in a unit of $W_{t}$ on $S_{t}$ and $\gamma_{21}$ is the effect of a change in a unit of $S_{t-1}$ on $W_{t}$. We note that the terms $\varepsilon_{S t}$ and $\varepsilon_{W t}$ are shocks in $S_{t}$ and $W_{t}$. Obviously if $b_{21}$ is not equal to zero, $\varepsilon_{S t}$ will have an indirect contemporaneous effect on $W_{t}$ and if $b_{21}$ is not equal to zero, $\varepsilon_{W t}$ will have an indirect contemporaneous effect on $S_{t}$.

Therefore, as in all VAR processes, each variable may be expressed as a linear combination of their lagged values and of the lagged values of all other variables in the group. In practice, VAR equations may also be expanded so as to include deterministic time trends and other exogenous variables.

This system observed in equations (5) and (6) after some matrix manipulations may be rewritten as:

$$
\begin{aligned}
& S_{t}=a_{10}+a_{11} S_{t-1}+a_{12} W_{t-1}+\varepsilon_{S t} \\
& W_{t}=a_{20}+a_{21} S_{t-1}+a_{22} W_{t-1}+\varepsilon_{W t}
\end{aligned}
$$

The literature presents the first system as a structural VAR or primitive system and the second one as a standard VAR.

If the variables of the model are integrated and belong to the same order, this system may be reparameterized as follows:

$$
\Delta y_{t}=m+b_{1} \Delta y_{t-1}+\ldots+b_{p-1} \Delta y_{t-p+1}-\Pi y_{t-1}+\varepsilon_{t}
$$

where $b$ are functions of $a s$ and $\Pi=I-a_{1}-\ldots-a_{p}$. In this case, if $\Pi=0$ the VAR should be specified in terms of first differences. The idea that variables should be stationary allows for a static equilibrium of the model.

Thus, there are two distinct approaches to VAR estimation. The first one consists of the direct estimation of the system represented by equation (4) or alternative reparameterization given by equation (9).

4 Sims (1980) questions the necessity that series should be stationary. The estimation of a VAR in first differences is recommended instead of a VAR in the level. He states that the aim of a VAR analysis is to determine the relationship between variables and not the estimation of parameters. However, estimation in first differences rules out the possibility of cointegration. 
The proposition is therefore the estimation and analysis of coefficients of the VAR model according to the format of equation (9) using impulse response functions.

\subsubsection{Vector Autoregressive with Markov Switch (MS-VAR)}

After Sims in 1980, VAR models have been widely investigated in empirical studies on macroeconomics. In time series analyses, the introduction of a model with Markov switching is based on Hamilton (1988, 1989).

The MS-VAR class provides tools for the estimation of VAR models with regime shifts. When a system is amenable to regime shifts, the parameters $\theta$ of a VAR process vary over time. However, the process may be time-constant conditional on an unobservable variable $\left(H_{t}\right)$ that indicates the prevailing regime in period $t$. Let $M$ be the number of feasible regimes and $H_{t} \in\{1, \ldots, M\}$, then the conditional probability density of an observable time series vector $\left\{y_{t}\right\}$ is given by:

$$
p\left(y_{t} / Y_{t-1}, H_{t}\right)=\left\{\begin{array}{c}
f\left(y_{t} / Y_{t-1}, \theta_{1}\right) \quad \text { if } \quad H_{t}=1 \\
\vdots \\
f\left(y_{t} / Y_{t-1}, \theta_{M}\right) \text { if } H_{t}=M
\end{array}\right.
$$

where $\theta_{m}$ is the vector of VAR parameters in regime $m=1, \ldots, M$ and $Y_{t-1}$ are observations $\left\{y_{t-j}\right\}_{j=1}^{\infty}$.

Thus for a given regime $H_{t}$, the time series vector $y_{t}$ is generated by a vector autoregressive process of order $p(\operatorname{VAR}(p))$ :

$$
E\left[y_{t} / Y_{t-1}, H_{t}\right]=v\left(H_{t}\right)+\sum_{j=1}^{p} A_{j}\left(H_{t}\right) y_{t-j},
$$

where $u_{t}$ is an innovation term:

$$
u_{t}=y_{t}-E\left[y_{t} / Y_{t-1}, H_{t}\right] \text {. }
$$

The innovation process is a white noise process with zero mean and variance-covariance matrix $\Sigma\left(H_{t}\right): u_{t} \sim \operatorname{NID}\left(0, \Sigma\left(H_{t}\right)\right)$.

If the VAR process is defined conditionally upon an unobservable regime as in equation (10), the description of the data generating process has to be completed via hypotheses about the regime generating process. A special characteristic of a Markov switching model is the hypothesis that the unobservable realization of a regime $H_{t} \in$ 
$\{1, \ldots, M\}$ is controlled by a Markov process, i.e., if each pattern is represented by an unobservable random state $H_{t}$ which may take on discrete values from 1 to $M$, then the probability of having reached a pattern $j$ today, given that we initially depart from a pattern $i_{0}$ and then pass to a pattern $i_{1}$ and so on and so forth until we get to yesterday's pattern $i$, will be, through the Markov property, just the same as the probability of having a pattern $j$ today, considering that yesterday we were in pattern $i$. Formaly:

$$
\operatorname{Prob}\left(H_{t}=j / H_{0}=i_{0}, H_{1}=i_{1}, \ldots, H_{t-1}=i\right)=\operatorname{Prob}\left(H_{t}=j / H_{t-1}\right)=p_{i j}
$$

Restricted to $p_{11}+p_{12}+\ldots+p_{1 m}=1$ and $0 \leq p \leq 1$, i.e., considering that we are in regime/state $i$ we have a certain probability to pass to the $M$ states of nature. The economic rationality behind this is that economy may be in different economic states.

The probabilities associated with each regime are expressed by a stochastic transition probability matrix $(M \times M)$ which describes the evolution of the Markov chain $\left(H_{t}\right)_{t \geq 0}$ of states $H_{t}$. This matrix can be expressed as:

$$
P=\left[\begin{array}{cccc}
p_{11} & p_{21} & \cdots & p_{M 1} \\
p_{12} & p_{22} & \cdots & p_{M 2} \\
\vdots & \vdots & \ddots & \vdots \\
p_{1 M} & p_{2 M} & \cdots & p_{M M}
\end{array}\right]
$$

To simplify, let $M=2$. Then the following Markov chain becomes,

$$
P=\left[\begin{array}{cc}
p_{11} & 1-p_{22} \\
1-p_{11} & p_{22}
\end{array}\right]
$$

If $p_{11}=1$, we then have an upper triangular matrix, i.e., whenever the process is in regime 1 it will never leave it. In this case we call regime 1 absorbing regime, as the process does not change any longer after entering this regime. This characteristic is quite common in financial or macroeconomic series, since there is no economic rationality. A Markov transition matrix is irreducible if there is no absorbing state, for instance, in case of a $(2 \times 2)$ matrix this will hold if $p_{11}<1$ and $p_{22}<1$.

An interesting piece of information that can be analyzed is the length of regimes. Considering the previously mentioned $P(M x M)$ matrix, the elements in the main diagonal contain the information about the length of a given regime. Our intention here is to know for how many periods, on average, a certain regime is in place. 
According to Kim and Nelson (1999), allowing $D=$ length of the regime $j$ we have: $D=1$ if $H_{t}=j$ and $H_{t+1} \neq j$, this implies that $P(D=1)=1-p_{i j}$, i.e., we simply have the probability of leaving regime $j$ because we were in it. In its turn, $D$ is equal to 2 if $H_{t}=$ $H_{t+1}=j$ and $H_{t+2} \neq j$, now this implies that $P(D=2)=p_{j j}\left(1-p_{j j}\right)$, i.e., we have the probability to repeat state $j$ once $\left(p_{j j}\right)$, times the probability of leaving $j\left(1-p_{j j}\right)$.

Following this reasoning, we may calculate the expected length of a regime:

$$
E(D)=\Sigma_{j=1}^{\infty} j . P(D=j)
$$

Therefore, $E(D)=1 .\left(1-p_{j j}\right)+2 p_{j j}\left(1-p_{j j}\right)+3 p^{2}{ }_{j j}\left(1-p_{j j}\right)+\ldots . .=1 /\left(1-p_{j j}\right)$. Having the value of $p_{j j}$ it is easy to calculate the expected length.

Back to MS-VAR models we have a mean-adjusted $\operatorname{VAR}(p)$ model with $M$ regimes following a Markov process:

$$
Y_{t}-\mu\left(H_{t}\right)=A_{l}\left(H_{t}\right)\left(Y_{t-1}-\mu\left(H_{t-1}\right)\right)+\ldots+A_{p}\left(H_{t}\right)\left(Y_{t-p}-\mu\left(H_{t-p}\right)\right)+u_{t}
$$

where $u_{t} \sim N I D\left(0, \Sigma\left(H_{t}\right)\right)$ and $\mu\left(H_{t}\right), A_{l}\left(H_{t}\right), \ldots, A_{p}\left(H_{t}\right), \Sigma\left(H_{t}\right)$ are functions of the parameters that describe the dependency of parameters $\mu, A_{l}, \ldots, A_{p}, \Sigma$ in realized regime $H_{t}$, that is: $\mu\left(H_{t}\right)=\mu_{l}$ if $H_{t}=1, \ldots, \mu\left(H_{t}\right)=\mu_{M}$ if $H_{t}=M$.

In this model, there is an immediate jump in the process mean in the subsequent period after a regime shift. However, it is sometimes more convincing to assume that the mean draws smoothly near a new level after the transition from one state to the other. In this regard, a model with a regime depending on the intercept term $v\left(H_{t}\right)$ may be used:

$$
Y_{t}=v\left(H_{t}\right)+A_{l}\left(H_{t}\right) Y_{t-l}+\ldots+A_{p}\left(H_{t}\right) Y_{t-p}+u_{t}
$$

Contrary to the linear VAR model, the mean adjusted by equation (15) and the intercept adjusted by equation (16) of an MS-VAR model are not equivalent. Krolzig (1997) shows that while a regime shift in mean $\mu\left(H_{t}\right)$ causes an immediate jump in the time series vector observed at its new level, the dynamic response of the regime shift from the first one to all others in the intercept term $v\left(H_{t}\right)$ is identical to an equivalent shock in the white noise series $u_{t}$.

In a more general model, all parameters may be conditioned on a state $H_{t}$ that follows a Markov chain. However, for empirical applications it might be more difficult to use a model where only some parameters are conditioned on a state with Markov property, whereas other parameters have constant regimes. Particularly, MS-VAR models may be 
introduced where autoregressive parameters, the mean or the intercept have dependent regimes and the error term is heteroskedastic or homoskedastic (see Chart 1).

CHART I - AUTOREGRESSIVE MODELS WITH MARKOV SWITCHING

\begin{tabular}{|c|c|c|c|c|c|}
\hline & \multicolumn{2}{|c|}{ MSM $\mu$ varying } & \multicolumn{3}{|c|}{ MSI Specification } \\
\hline & & & constant $\mu$ & varying $\mathrm{v}$ & constant V \\
\hline \multirow{2}{*}{ constant $A_{j}$} & constant $\sum$ & MSM-VAR & linear MVAR & MSI-VAR & linear VAR \\
\hline & varying $\Sigma$ & MSMH-VAR & MSH-MVAR & MSIH-VAR & MSH-VAR \\
\hline \multirow[t]{2}{*}{ Variable $A_{j}$} & constant $\Sigma$ & MSMA-VAR & MAS-MVAR & MSIA-VAR & MAS-VAR \\
\hline & varying $\Sigma$ & MSMAH-VAR & MSAH-MVAR & MSIAH-VAR & MSAH-VAR \\
\hline
\end{tabular}

These parameters have the following meaning:

$\mathrm{M} \Rightarrow$ mean with Markov switching

$\mathrm{I} \Rightarrow$ intercept with Markov switching

$\mathrm{A} \Rightarrow$ autoregressive parameters with Markov switching

$\mathrm{H} \Rightarrow$ Heteroskedasticity with Markov switching

The models in boldface in Chart 1 are the ones used in the present paper.

To distinguish VAR models with time-invariant intercept and mean, the adjusted mean of an autoregressive vector with $\operatorname{MSVAR}(p)$ is used. Obviously, if the specifications of MSI and MSM models have $p=0$, they are equivalent.

Maximum likelihood can be used to estimate the MS-VAR model. The maximization of a likelihood function of an MS-VAR model results in an iterative estimation technique to obtain estimations of autoregression parameters and of the transition probabilities controlled by the unobserved states of a Markov chain. In other words, the vector of parameters that maximizes the likelihood for the considered observations is defined.

The likelihood function is merely the product of the density functions for each observation that includes the probability that this one could be generated in a given regime using the available information. Basically, its simplest representation would be:

$$
L n L=\sum_{t=1}^{T} \ln \left[\sum_{H_{t}=0}^{1} f\left(Y_{t} / H_{t}, \psi_{t-1}\right) \cdot P\left(H_{t} / \psi_{t-1}\right)\right]
$$


where $\psi_{t-1}=$ all information available up to $t-1$. One should recall that the structure for the variation of $H_{t}$ over time is based on the probability matrix described previously.

This estimation is based on an implementation of an EM algorithm proposed by Hamilton (1990) for this class of models. An alternative estimation of the maximum likelihood of an MS(M)-VAR $(p)$ model is given by Krolzig (1997). ${ }^{5}$

Before estimating the model, a single set of parameters should be specified. The maximum likelihood estimation takes for granted that the model is at least locally identified. In MS-VAR models, an identification problem may be superficially caused by an exchange capacity at the state level. As the state levels of a Markov chain $\left\{H_{t}\right\}$ can be switched without changing the law of processes of parameters and of observable variables, MS-VAR models are not strictly identified. However, these exchanges may be prevented by some intrinsic behaviors regarding the characteristics of the regimes. This means that states can be organized in an $\operatorname{MSM}(M)-\operatorname{VAR}(p)$ model so that they have an increasing mean for each $k t h$ variable, $\mu_{k 1}<\mu_{k 2}<\ldots<\mu_{k M}$, which do not restrict empirical analyses.

This section showed the techniques used to capture the relationship between monetary and fiscal policies in Brazil, giving special emphasis on the MS-VAR model.

\section{EMPIRICAL RESULTS}

The aim of this section is to show the results from and discussions about VAR and MS-VAR models regarding the interaction of monetary and fiscal policies in Brazil. The variables used are: public sector borrowing requirements as a primary concept, ${ }^{6}$ domestic public debt held by the public, over-Selic interest rate and gross domestic product at current prices. The series has a monthly periodicity, with values accumulated during twelve months from January 1995 to September 2003.

Prior to model estimation, stationarity tests are performed for the series under study. The result of the rejection of the unit root null hypothesis is not confirmed by any of the series, that is, all of them are nonstationary in the level.

5 There are still some studies that use and explain the MS-VAR methodology such as: Krolzig (1996, 1998, 2000) and Krolzig and Toro (2000).

6 That is it does not include interest payments. 


\subsection{VAR Model Estimations}

Since primary surplus/GDP and public debt/GDP variables have a unit root, a VAR is estimated in first differences and consequently the impulse response functions of the system are obtained. As VAR methodology reveals a possible discrepancy in results due to the ordinations adopted for the variables in the model, the two possible ordinations are used in this case. The ordination in which the series of primary surplus/GDP comes first allows for a contemporaneous effect to innovation on public debt/GDP, which is consistent with a non-Ricardian regime (where the nominal GDP should jump in equilibrium to cause the existing debt value to equal the present value discounted from primary surpluses). The ordination in which public debt/GDP comes first does not allow for a contemporaneous shock effect on the debt proper, which makes more sense in a Ricardian regime.

Recalling the equations to be estimated by the VAR model, we have:

$$
\begin{aligned}
& S_{t}=a_{10}+a_{11} S_{t-1}+a_{12} W_{t-1}+\varepsilon_{S t} \\
& W_{t}=a_{20}+a_{21} S_{t-1}+a_{22} W_{t-1}+\varepsilon_{W t}
\end{aligned}
$$

where $\mathrm{S}_{t}$, is the primary surplus/GDP, $W_{t}$ is the public debt/GDP and $\varepsilon_{S t}$ and $\varepsilon_{W t}$ are white noises with standard deviations $\sigma_{S}$ and $\sigma_{W}$

Figures 1 and 2 show the impulse response functions for an innovation in the primary surplus/GDP. The aim here is to analyze the response of public debt/GDP forward one period to the innovation in the primary surplus/GDP. If the surpluses are positively correlated and the debt in $t+1$ decrease, we have an MD regime, if not, we have a DF regime. But if the surpluses are negatively correlated, we may have an MD or an FD regime generating an identification problem.

In case of autocorrelation, the results indicate the presence of positive and significant autocorrelation for all the first lags in the primary surplus/GDP ratio, as pointed out in Table 1. Confirming this analysis, the impulse response functions show that a positive innovation in the surplus leads to a new surplus in the subsequent period.

Therefore, we may identify the predominance of an MD or an FD regime by analyzing Figures 1 and 2 . Once it was founded a positive correlation between an innovation in the surplus today and future surpluses, and once the public debt/GDP response from period 2 onwards was negative but not significant, we may affirm that this response is followed by an MD regime. 
FIGURE 1 - ORDINATION: PUBLIC DEBT/GDP, PRIMARY SURPLUS/GDP

Response to One S.D. Innovations \pm 2 S.E.

Response of D(DIVIDA) to D(SUPERAVIT)
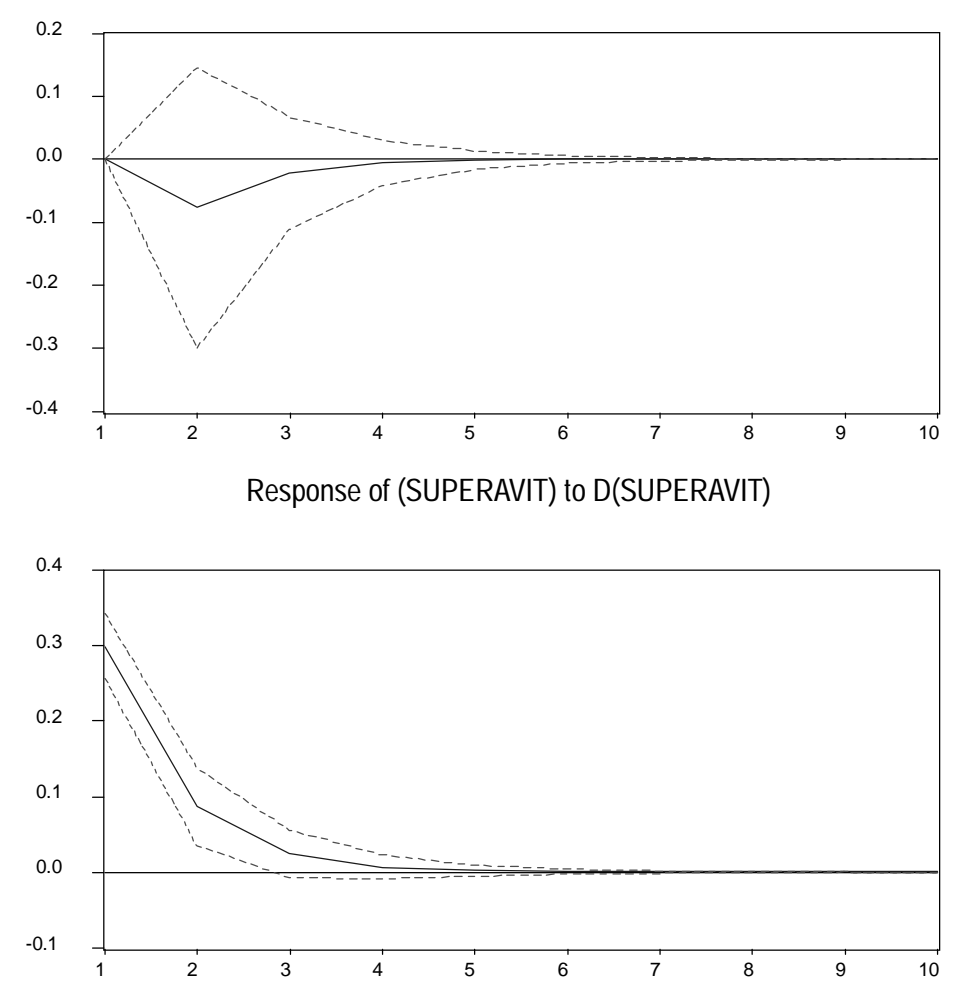

TABLE 1 - PRIMARY SURPLUS/GDP CORRELOGRAM

\begin{tabular}{ccccc}
\hline & AC & PAC & Q-Stat & Prob \\
\hline 1 & 0.969 & 0.969 & 101.48 & 0.000 \\
2 & 0.938 & -0.019 & 197.50 & 0.000 \\
3 & 0.900 & -0.142 & 286.63 & 0.000 \\
4 & 0.854 & -0.140 & 367.73 & 0.000 \\
5 & 0.800 & -0.147 & 439.67 & 0.000 \\
6 & 0.748 & 0.010 & 503.10 & 0.000 \\
7 & 0.694 & -0.012 & 558.26 & 0.000 \\
8 & 0.640 & -0.012 & 605.64 & 0.000 \\
9 & 0.588 & 0.028 & 646.16 & 0.000 \\
10 & 0.539 & -0.016 & 680.47 & 0.000 \\
11 & 0.490 & -0.026 & 709.13 & 0.000 \\
12 & 0.443 & -0.011 & 732.86 & 0.000 \\
\hline
\end{tabular}


FIGURE 2 - ORDINATION: PRIMARY SURPLUS/GDP, PUBLIC DEBT/GDP.

Response to One S.D. Innovations \pm 2 S.E.

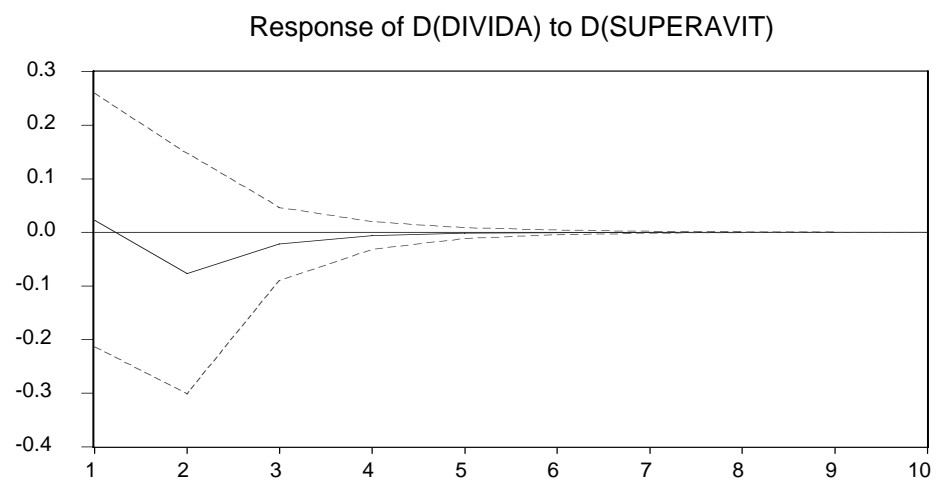

Response of D(SUPERAVIT) to D(SUPERAVIT)

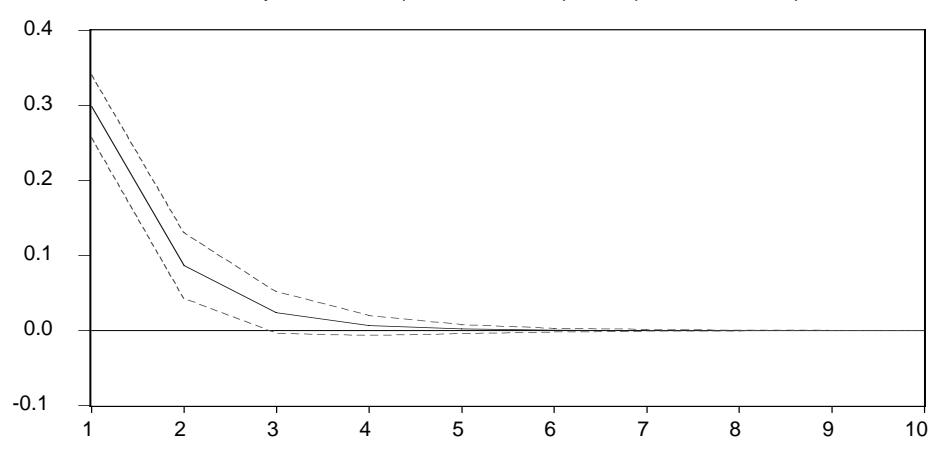

Thus, the results obtained for the determination of the regime, that is, if a positive shock to surplus reduces the debt in the subsequent period leading to an MD regime or if a positive shock to surplus increases the debt in the subsequent period leading to an FD regime, are beyond any doubt. As the concern with the debt response is one step ahead of the shock to surplus, the determination of a monetary dominance regime in Brazil becomes quite clear.

In summary, we found some evidence of an $\mathrm{MD}$ regime for the studied period. The debt response one or more periods forward to an innovation in the surplus was negative but not significant, that is, in subsequent periods the debt decrease again with a surplus in each period that produces another surplus and so on and so forth, thus characterizing an MD regime. 
FIGURE 3 - ORDINATION: D(LOGDEBT), D(SURPLUS) AND D(LOGGDP)

Response to One S.D. Innovations \pm 2 S.E.

Response of D(LOGDIVIDA) to D(SUPERAVIT)
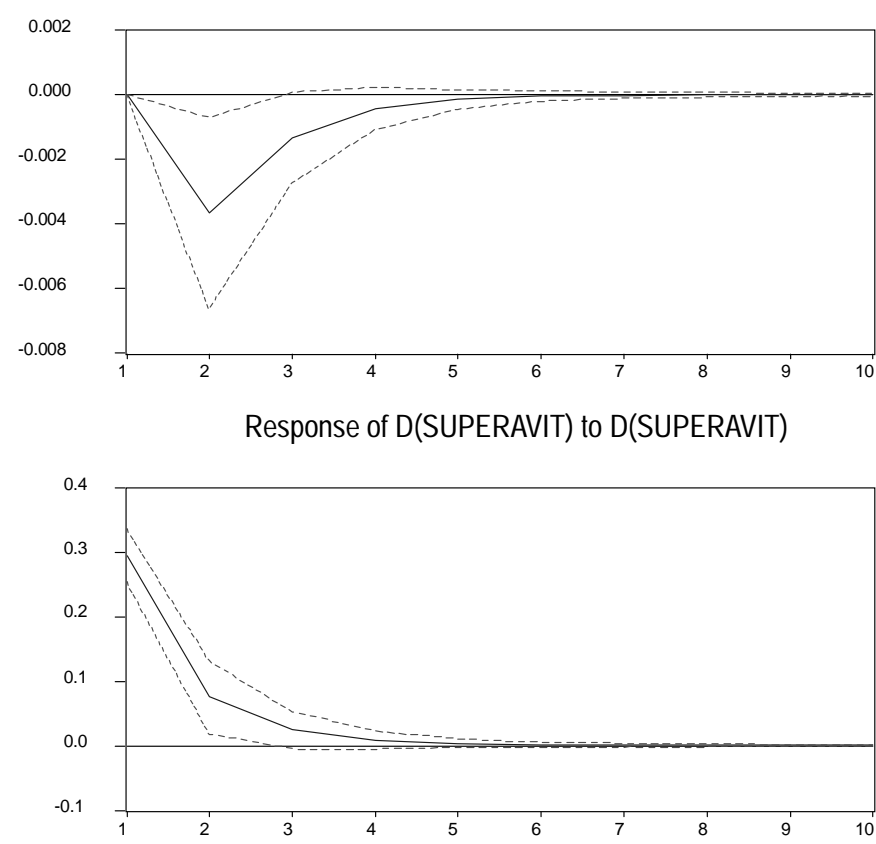

Response of D(LOGPIB) to D(SUPERAVIT)

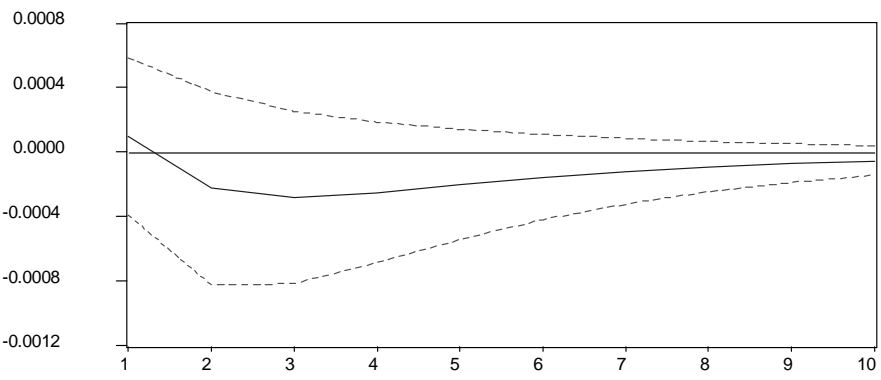

Another analysis, carried out to confirm the results, can also be made by assessing the behavior of nominal GDP. ${ }^{7}$ According to Ricardian equivalence changes in the government budget and in public debt do not exert an effect on aggregate demand, Ricardian regime. On the other hand, in a non-Ricardian regime, in the presence of nominal rigidity, it is believed that aggregate demand variations resulting from fiscal shocks cause

7 Study conducted by Silva and Rocha (2003) for the Brazilian economy from 1966 to 2000. 
variations in the real level of economic activity and in the real interest rate, as well as oscillations in the inflation rate.

Thus, to check whether a positive innovation in the surplus reduces the nominal income in the same period and increases government debt, as pointed out by Canzoneri, Cumby and Diba (2000), we estimate a VAR with 1 lag and intercept for the following variables: Primary surplus/GDP, LogDebt which corresponds to the logarithm of government debt in nominal terms and LogGDP, the logarithm of nominal GDP. All variables are used in first difference.

As the nominal GDP is expected to respond to the innovation in the surplus in the case of a non-Ricardian regime, the adopted ordination was: LogDebt, surplus, LogGDP. The impulse response functions of the estimated VAR with 1 lag and intercept are pictured in Figure 3.

The obtained result, consistent with our expectations, was that an innovation in the surplus reduces the nominal income but also decreases the level of debt in the subsequent period. This indicates that this analysis does not confirm the existence of a nonRicardian regime. In other words, there is a commitment of economic authorities towards surplus generating policies in order to reduce public debt.

The following model helps us to understand this relationship between the aims of Brazilian economic policies leading to a monetary regime.

\subsection{MS-VAR Model Estimations}

This section presents the major methodological innovation in the literature on economic policy interactions. As a matter of fact, the use of MS-VAR models for the construction of empirical economic studies is quite recent. Some works date back to the late 1990s, e.g. Krolzig (1997, 1998, 2000).

Introducing the results, just as in the estimation of the VAR model, we take the first difference of the primary surplus/GDP and Selic series and analyze them in order to observe the relationship of these variables in the selected period.

This study is specifically concerned with the MSMH(2)-VAR(1) and MSIH(2)$\operatorname{VAR}(1)$ methodology, VAR models with one lag where mean and intercept follow a Markov process in two regimes, which may be respectively derived from equations (15) and (16) as follows: 


$$
\begin{aligned}
& \left(\Delta Y_{t}-\mu_{2}-\left(\mu_{1}-\mu_{2}\right) \xi_{1 t}\right)=A_{1}\left(\Delta Y_{t-1}-\mu_{2}-\left(\mu_{1}-\mu_{2}\right) \xi_{1 t-1}\right)+u_{t} \\
& \Delta Y_{t}=v_{2}+\left(v_{1}-v_{2}\right) \xi_{1 t}+A_{1} \Delta Y_{t-1}+u_{t}
\end{aligned}
$$

where $\Delta Y_{t}$ is a vector of two variables differentiated once, since they are not stationary in the level. These variables are primary surplus and selic interest rate, as previously mentioned. We use the VAR in first differences, since the variables are not cointegrated, otherwise we would use the VEC methodology.

The justification for the analysis of models is due to the rejection of the null hypothesis of the LR test for the selection of models as shown in the table 20. The results obtained for both models are quite similar, that is, the analysis of possible regime shifts in the behavior of Brazilian economic policy indicates that both variations in the mean and in the intercept capture the same effect. In this sense, comments about the MSMH-VAR model are made.

\section{TABLE 2 - LR TEST FOR SELECTION OF MODELS}

\begin{tabular}{lcc}
\hline $\mathrm{H}_{0}: \operatorname{MSM}(2)-\operatorname{VAR}(1)=\operatorname{MSMH}(2)-\operatorname{VAR}(1)$ & $\mathrm{LR}=93.9562^{*}$ & $\begin{array}{c}\text { Choice } \\
\mathrm{H}_{\mathrm{a}}: \operatorname{MSM}(2)-\operatorname{VAR}(1) \neq \operatorname{MSMH}(2)-\operatorname{VAR}(1)\end{array}$ \\
\hline $\mathrm{H}_{0}: \operatorname{MSI}(2)-\operatorname{VAR}(1)=\operatorname{MSIH}(2)-\operatorname{VAR}(1)$ & $\mathrm{LR}=92.4306^{*}$ & Choice \\
$\mathrm{H}_{\mathrm{a}}: \operatorname{MSI}(2)-\operatorname{VAR}(1) \neq \operatorname{MSIH}(2)-\operatorname{VAR}(1)$ & & $\operatorname{MSIH}(2)-\operatorname{VAR}(1)$ \\
\hline
\end{tabular}

Note $\left(^{*}\right)$ : As $\chi_{95}^{2}=5.99$, value of the chi-squared statistic with 2 degrees of freedom or with two restrictions on the null hypothesis, this implies in inequality of models due to the $5 \%$ significance of the LR test, and then the unrestricted model is selected, as suggested in the literature.

By making a careful analysis of Table 3 and Figure 4, we find a lower mean in regime 1 than in regime 2. However, the standard deviation of the surplus between regimes remains virtually unchanged, indicating that only the behavior of interests explains the variation in regimes. This may show the predominance of a single regime (1), whereas regime (2) would only be an adjustment of policies originating from macroeconomic disturbances in economy and not a change in paradigm representing a new regime.

The meaning of each regime may be determined by analyzing the signs assumed by the means of the model. The signs followed the same direction and were negative for the surplus and selic in the first regime and positive in the second regime. This means that in the first situation both policies were expansionist, and that in the second situation, they were contractionist. Muscatelli et al. (2002) identify this kind of behavior of monetary and fiscal policies as complementary. Policies that indicated contrary paths (contractionist and expansionist and vice versa) were classified as substitute. Therefore, 
signs with the same direction in regime (1) and in regime (2) characterize the period as a set of complementary policies.

By analyzing regime (2) separately, we note that this regime is present in more turbulent moments of the Brazilian economy in the post-Real period, as shown in Table 4 (effect after the Mexican crisis in early 1995, Asian crisis in late 1997, Russian crisis in late 1998 and later suppression of fixed exchange rate in early 1999 with adoption of inflation targeting policies).

Therefore, the behavior of monetary policy in regime (2) would be just a response to these external shocks instead of a policy that varies according to a change in the macroeconomic paradigm. At those times, monetary policy reactions were quite contractionist, that is, with a large increase in interest rates, whereas the fiscal policy did not show a significant change in its path.

Based on this analysis, we may say that, during the study period, regime 1 would have a length of approximately 30 periods against a length of 4 periods for regime 2 , as shown in Table 4.

However, the economic data indicate that these results are not consistent with the economic scenario of that period. This may have occurred due to model misspecification.

Thus, another way to understand the relationship of these policies within this time interval would be to analyze an MS-VAR model including a dummy variable that could eliminate the supposed shocks observed in regime (2) of the previous model. As the results indicated absence of regime (2), this new model could explain what happened.

TABLE 3 - MSMH(2)-VAR(I) MODEL FOR (SURPLUS, INTERESTS), 1995 (3) $2003(9)$

\begin{tabular}{lcc}
\hline Coefficients & $\Delta$ Surplus & $\Delta$ Selic \\
\hline Mean(reg 1) & -0.036181 & -0.756890 \\
Mean (reg 2) & $(-0.8065)$ & $(-3.0203)$ \\
& 0.267584 & 1.247934 \\
$\Delta$ Surplus(-1) & $(2.5439)$ & $(0.4288)$ \\
& 0.277801 & 1.730688 \\
$\Delta$ Selic(-1) & $(2.9948)$ & $(2.2073)$ \\
& 0.002117 & -0.121612 \\
SE (reg 1) & $(0.3887)$ & $(-2.3436)$ \\
SE(reg 2) & 0.290548 & 2.162210 \\
log-likelihood & 0.298426 & 12.888363 \\
\hline
\end{tabular}


FIGURE 4 - PROBABILITY OF THE MSMH(2)-VAR(1) MODEL

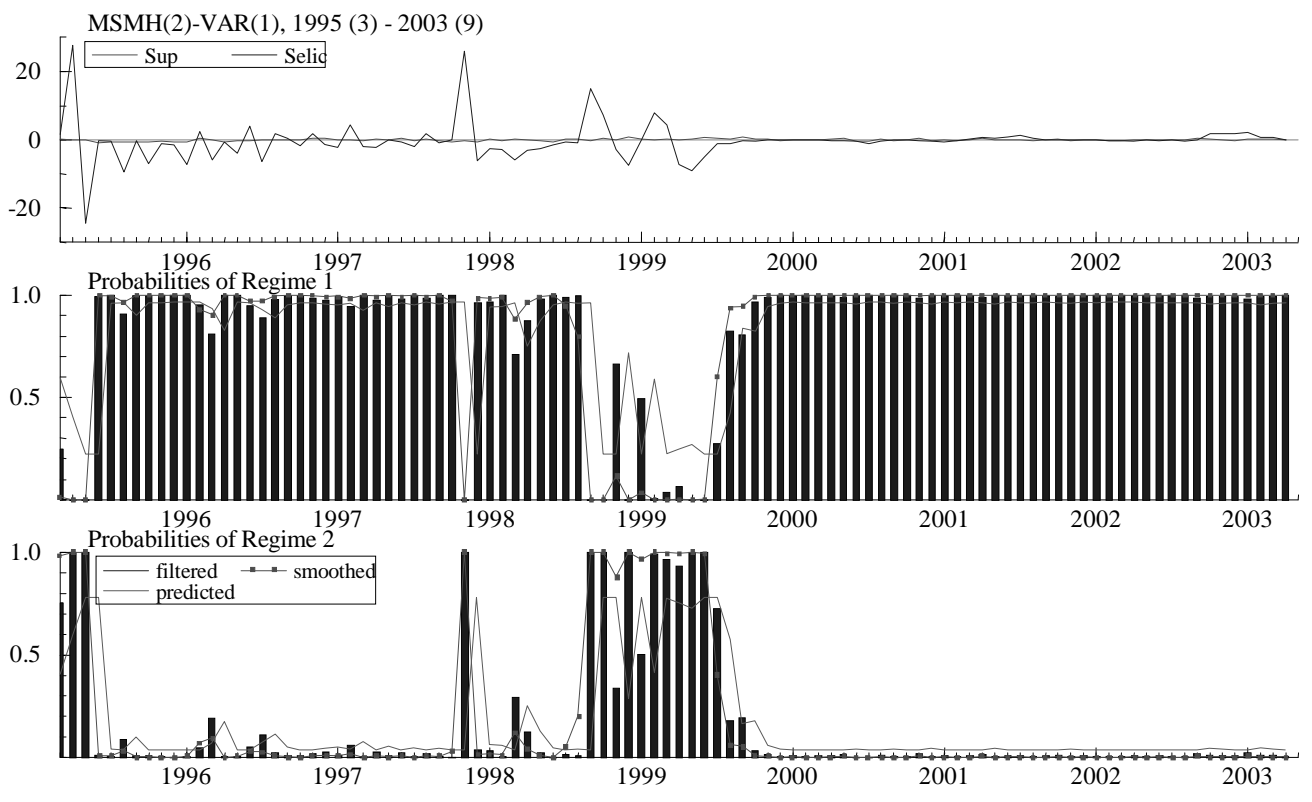

Therefore, the new model would be of the MSIH(2)-VARX(1) type. The difference now lies exactly in the inclusion of an exogenous dummy variable represented by $X$ in the description of the model. The new results are shown in Tables 6, 7, 8 and Figure 5.

This new analysis shows a clear division between regimes. The exact period of prevalence of each regime is presented in Table 7. Now regime (2) of the MSIH(2)$\operatorname{VARX}(1)$ model, in the pre-1999 period, indicates a contractionist monetary policy with high interest rates and a fiscal policy with an expansionist trend characterized by successive decreases in surplus; on the other hand, in the post-1999 period, regime (1), the monetary policy compared to the previous period is expansionist, with relatively low interest rates and a fiscal policy that is increasingly contractionist. All this is due to the agreement with the IMF, situations that actually occurred in the Brazilian economy. 
TABLE 4 - CLASSIFICATION OF THE REGIME OF THE MSMH(2)-VAR(1) MODEL

\begin{tabular}{lccc}
\hline Period & Regime 1 & \multicolumn{1}{c}{ Period } & Regime 2 \\
\hline 1995:6-1997:10 & {$[0.9867]$} & $1995: 3-1995: 5$ & {$[0.9953]$} \\
$1997: 12-1998: 8$ & {$[0.9484]$} & $1997: 11-1997: 11$ & {$[1.0000]$} \\
$1999: 7-2003: 9$ & {$[0.9871]$} & $1998: 9-1999: 6$ & {$[0.9845]$} \\
\hline
\end{tabular}

TABLE 5 - TRANSITION MATRIX AND LENGTH OF REGIMES OF THE $M S M H(2)-V A R(1) M O D E L$

\begin{tabular}{lccccc}
\hline Transition & Regime 1 & Regime 2 & \#Obs. & Prob. & Length \\
\hline Regime 1 & 0.9675 & 0.0325 & 87.7 & 0.8719 & 30.73 \\
Regime 2 & 0.2215 & 0.7785 & 15.3 & 0.1281 & 4.51 \\
\hline
\end{tabular}

Regimes can be characterized as defined in Table 6 by analyzing the signs of the constants in both regimes. This new result shows opposite signs for the policies in both regimes, contrary to what happened previously. However, again, both regimes indicate the same behavior. They are now substitutes throughout the period, only shifting their regime from contractionist to expansionist in case of the fiscal policy and from expansionist to contractionist in the case of monetary policy, thus both regime (1) and regime (2) were classified as regimes with substitute policies.

TABLE 6 - MSIH(2)-VARX(1) MODEL FOR (SURPLUS, SELIC), 1995 (3) - 2003 (9)

\begin{tabular}{lrr}
\hline Coefficients & $\Delta$ Surplus & \multicolumn{1}{c}{$\Delta$ Selic } \\
\hline Constant (reg 1) & 0.037270 & -0.022520 \\
& $(1.0821)$ & $(-0.2862)$ \\
Constant (reg 2) & -0.023325 & 0.051404 \\
& $(-0.3778)$ & $(0.0360)$ \\
$\Delta$ Surplus(-1) & 0.218928 & 0.402002 \\
& $(2.2846)$ & $(1.2552)$ \\
$\Delta$ Selic(-1) & 0.004954 & 0.568930 \\
& $(0.5952)$ & $(11.4761)$ \\
Dummy(-1) & -0.137715 & -4.667273 \\
& $(-0.6715)$ & $(-3.1878)$ \\
SE (reg 1) & 0.237198 & 0.555344 \\
SE(reg 2) & 0.353773 & 9.675421 \\
log-likelihood & -244.4535 & \\
\hline
\end{tabular}


We may affirm that throughout the study period the policies were weak substitutes due to the fact that the coefficients of determination of regimes were too close to zero. And comparatively to the previous situation, the standard deviation of the fiscal policy between regimes remains virtually unchanged, and the relevance is in the behavior of the monetary policy.

\section{TABLE 7 - CLASSIFICATION OF THE REGIME OF THE MSIH(2)-VARX(1) $M O D E L$}

\begin{tabular}{lccc}
\hline Period & Regime 1 & Period & Regime 2 \\
\hline 1998:4 - 1998:8 & {$[0.9639]$} & $1995: 3-1998: 3$ & {$[0.9916]$} \\
$1999: 6-2003: 9$ & {$[0.9863]$} & $1998: 9-1999: 5$ & {$[0.9962]$} \\
\hline
\end{tabular}

TABLE 8 - TRANSITION MATRIX AND LENGTH OF REGIME OF THE MSIH(2)-VARX(1) MODEL

\begin{tabular}{lccccc}
\hline Transition & Regime 1 & Regime 2 & \#Obs. & Prob. & Length \\
\hline Regime 1 & 0.9719 & 0.0281 & 56.5 & 0.6319 & 35.56 \\
Regime 2 & 0.0483 & 0.9517 & 46.5 & 0.3681 & 20.71 \\
\hline
\end{tabular}

FIGURE 5 - PROBABILITY OF THE MSIH(2)-VARX(1) MODEL

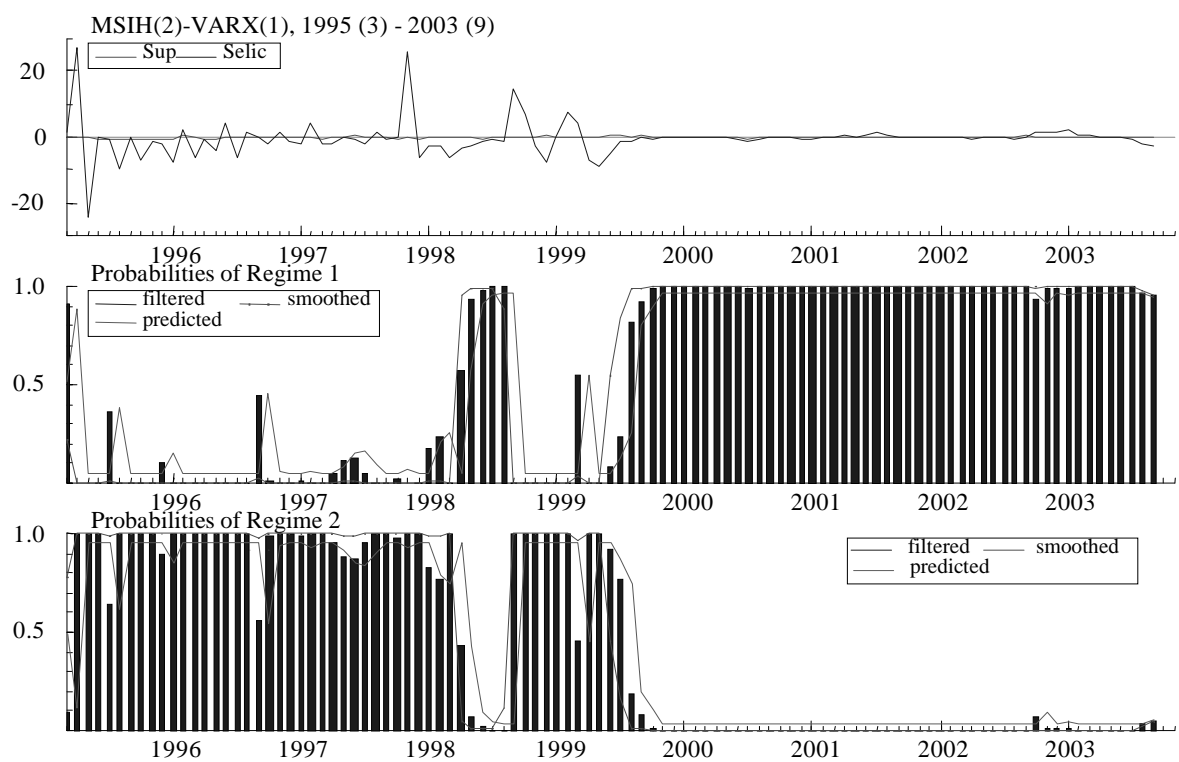


Table 8 shows that the length of regimes was more balanced. Regime (1) prevailed for approximately 35 periods against a length of 20 periods for regime (2). This piece of information is only important to know for how long each cycle, expansionist or contractionist, lasted, once they occurred interchangeably throughout the period.

Thus, the results of the last model are pre-eminent since they encompass the problem more completely, including the dummy variable for the periods of international crises.

With these results we identify a game where the monetary authority plays first (or it is active) while the fiscal authority have a passive behavior determining the surplus and debt levels to the prices given by the monetary policy. This is favorable to the monetary dominance, as founded in the VAR model. If the game happened in the inverse way we would have evidences of a fiscal regime.

\section{FINAL REMARKS}

The present study empirically analyzes price level determination for the Brazilian economy during the post-Real period and the characterization of fiscal or monetary dominance regimes with the interactions of monetary and fiscal policies throughout this period.

To achieve the first empirical objective, we used VAR models and analyzed their impulse response functions. We found out evidence of an MD regime for the study period. The debt response in one or more subsequent periods to the innovation in the surplus was negative but not significant that is, in subsequent periods the debt decreases again in spite of a surplus in each period that generates another surplus and so on and so forth, thus characterizing an MD regime.

By also analyzing the behavior of nominal GDP, we found that an innovation in the surplus reduces the nominal income, but decreases the level of debt in the subsequent period. This indicates that this analysis does not confirm a non-Ricardian regime.

There is still a paucity of empirical studies on the interdependence between monetary and fiscal policies and their interactions as key macroeconomic variables. This occurs despite the increasing number of theoretical models that focus on the role of fiscal rules in the management of monetary policy to affect the price level.

A special focus of analysis concerned the introduction of MS-VAR models with two regimes. The problem studied here was how Brazilian monetary and fiscal policies interacted during the post-Real period. We applied a vector autoregressive model with 
Markov switching to estimate the time-varying parameters. The advantage of this approach over VAR models is that it allows determining changes in the behavior of policies in each regime.

The results indicated opposite signs for policies in each regime, however they show the same type of behavior. They are substitutes throughout the period, and only shift from contractionist to expansionist in the case of fiscal policy and from expansionist to contractionist in the case of monetary policy, then both regime (1) and regime (2) were classified as regimes with substitute policies. We may also affirm that policies were weak substitutes during the study period since the coefficients of determination of regimes were too close to zero. With these results we identify a game where the monetary authority plays first (or it is active) while the fiscal authority have a passive behavior determining the surplus and debt levels to the prices given by the monetary policy. This is favorable to the monetary dominance, as founded in the VAR model.

In conclusion, the macroeconomic coordination between Brazilian policies was virtually of the substitute type during the study period, with a predominantly monetary regime. This economic behavior adopted by the Brazilian government in the latest years, shown in our results here, have been useful in minimizing the level of uncertainty, but the Brazilian fiscal problems are far from being balanced, and this could bring some problems in the medium and long run.

It is common knowledge that fiscal dominance in its simplest definition occurs when inflation predominantly results from fiscal problems and not from the lack of monetary control. Based on the results obtained herein, the government should be attentive to the monetary control and to situations in which the debt stock is uncomfortably close to the maximum sustainable, using the real interest rate compatible with economic growth as a parameter. In this scenario, an increase in the nominal interest rate, even if temporary, could increase the debt stock beyond the maximum sustainable, through its impact on the debt service.

The empirical observations regarding the propositions presented here are subject to several corrections and criticisms because the literature on price determination, according to the fiscal theory of price level, has not been significantly explored. In addition, Brazilian publications are mostly theoretical. This type of scientific limitation hinders the comparison of results. Therefore, the present study attempts to contribute to the theoretical and empirical improvement of this theory by seeking to elucidate how the interaction of economic policies affects the price level.

It should be underscored that the methodology used herein can be improved as the temporal availability of the series increases. The use of monthly data in the proposed 
analyses is not recommended in this case. However, there was a necessity for degrees of freedom in the econometric part. On the other hand, the period of economic stabilization Brazil has been through after the implementation of the Real plan makes it relevant to study the problems related to the behavior of economic policies.

A possible alternative is to analyze the sensitivity of the debt to the exchange rate in a fiscal dominance regime; this would be another relevant leg of the equation. In these terms, an increase in interest rates would depreciate the exchange rate and increase inflation, that is, the monetary policy would lose its efficiency over the prices. Another suggestion is to apply a model for two countries as far as price determination is concerned. In a model for Brazil and Argentina there would be two monetary and two fiscal authorities.

\section{REFERENCES}

Canzoneri, M. B.; Cumby, R. E; Diba, B. T. Is the price level determined by the needs of fiscal solvency ? Forthcoming American Economic Review, 2000.

Cochrane, J. H. Money as stock: price level determination with no money demand. NBER Working Paper N. 7498, January 2000.

Da Silva, E.; Rocha, F. Teoria fiscal e a plausibilidade de regimes não-ricarianos no Brasil. In: ASSOCIAÇÃO NACIONAL DE CENTROS DE PÓS-GRADUAÇÃO EM ECONOMIA, 2003, Porto Seguro. Anais ... Porto Seguro/Bahia: ANPEC, 2003.

Debrun, X.; Wyplosz, C. Onze gouvernments et une banque centrale. Revue d' Economie Politique, v. 3, p. 387-420, 1999.

Fisher, I. The equation of exchange 1896-1910. American Economic Review, v. 1, p. 296-305, 1911.

Hamilton, J. D. Rational expectations econometric analysis of changes in regime. An investigation of the term structure of interest rates. Journal of Economic Dynamics and Control, v. 12, p. 385-423, 1988.

. A new approach to the economic analysis of nonstationary time series and the business cycle. Econometrica, v. 57, p. 357-384, 1989.

Analysis of time series subject to changes in regime. Journal of Econometrics, v. 45, p. 39-70, 1990.

Kim, C; Nelson, C. State-space models with regime switching: classical and Gibbs-sampling approaches with applications. MIT, 1999.

Krolzig, M. Statistical analysis of cointegrated VAR processes with Markovian regime shifts. SFB 373 Discussion Paper 25/1996, Humboldt Universit" at zu Berlin, 1996. 
. Markov switching vector autoregressions. Modelling, statistical inference and application to business cycle analysis. Berlin: Springer, 1997.

Econometric modelling of Markov-switching vector autoregressions using MSVAR for Ox. Discussion Paper, Department of Economics, University of Oxford: http://www.economics.ox.ac.uk/hendry/krolzig. 1998.

Predicting Markov-switching vector autoregressive processes. Working Paper, Oxford: Department of Economics and Nuffield College, 2000.

Krolzig, M.; Toro, J. A new approach to the analysis of shocks and the cycle in a model of output and employment. Working Paper, EUI: Florence, 2000.

Leeper, E. Equilibria under active and passive monetary and fiscal policies. Journal of Monetary Economics, v. 27, p. 129-147, 1991.

Luporini, V. The behavior of the Brazilian federal domestic debt. In: ASSOCIAÇÃO NACIONAL DE CENTROS DE PÓS-GRADUAÇÃO EM ECONOMIA, 2001, Salvador. Anais ... Salvador: ANPEC, 2001.

Mélitz, J. Some cross-country evidence about debt, deficits, and the behaviour of monetary and fiscal authorities. CEPR Discussion Paper n.1653, 1997.

. Some cross-country evidence about fiscal policy behaviour and consequences for EMU. European Economy, Reports and Studies 2, p. 3-21, 2000.

Muscatelli, V.; Tirelli, A.; Trecroci, C. Monetary and fiscal policy interactions over the cycle: some empirical evidence. Manuscript, 2002.

Pastore, A. Déficit público, a sustentabilidade das dívidas interna e externa, senhoriagem e inflação: uma análise do regime monetário brasileiro. Revista de Econometria, v. 14, n.2, p. 177-234, 1995.

Rocha, F. Um teste dos limites do poder da política monetária. Estudos Econômicos, v. 26, n. 3, p. 309-333, set-dez, 1996.

. Long-run limits on the Brazilian government debt. Revista de Economia Brasileira, v. 51, n.4, p. 447-470, 1997.

Sargent, T. J. Dynamic macroeconomic theory. Cambridge: Harvard University Press, 1987.

Sargent, T. J; Wallace, N. Some unpleasant monetarist arithmetic. Federal Reserve Bank of Minneapolis. Quarterly Review v. 5, p. 1-17, 1981.

Semmler, W.; Zhang, W. Monetary and fiscal policy interactions: some empirical evidence in the Euro-area. Germany: Bielefeld University, Working Paper $\mathrm{n}$. 48, March, 2003.

Sims, C. Macroeconomics and reality. Econometrica, v. 48, n. 1, p. 1-48, 1980.

A simple model for study of the determination of the price level and the interaction of monetary and fiscal policy. Economic Theory, v. 4, p. 381-399, 1994. 
Smaghi, B.; Casini, C. Monetary and fiscal policy co-operation: institutions and procedures in EMU. Forthcoming in the Journal of Common Market Studies, 2000.

Tanner, E; Ramos, A. M. Fiscal sustainability and monetary versus fiscal dominance: evidence from Brazil, 1991-2000. In: LATIN AMERICAN AND CARRIBBEAN ECONOMIC ASSOCIATION, 2000, Rio de Janeiro. Anais ... Rio de Janeiro: LACEA, 2000. cd-rom.

Van Aarle, B.; Garretsen, H.; Gobbin, N. Monetary and fiscal policy transmission in the euro-area: evidence from a VAR analysis. Manuscript, 2001.

Woodford, M. Monetary policy and price level determinacy in a cash-in-advance economy. Economic Theory, v. 4, p. 345-380, 1994.

Price level determinacy without control of a monetary aggregate. Carnegie Rochester Conference Series on Public Policy v. 43, p. 1-46, 1995.

. Control of the public debt: a requirement for price stability? NBER Working Papers n. 5684, July 1996.

. Public debt and the price level. Princeton University, July 7, 1998 (mimeo).

. Comment. In: Blanchard, Olivier; Rotemberg, Julio J. (eds.), NBER Macroeconomics Annual 1998, p. 390-419, 1999.

We would like to thank Frederico H. Souza (CNPq), Philipe E. S. Berman (FAPERGS) and Marcelo C. Grieber $(\mathrm{CNPq})$, Felipe $\mathrm{G}$. Ribeiro $(\mathrm{CNPq})$ for their research assistantship.

Contacting author: Universidade Federal do Rio Grande do Sul - Programa de Pós-Graduação em Economia - Av. João Pessoa, 52, sala 33B - CEP 90040-000 - Porto Alegre - RS.

E-mails: mlfialho@ppge.ufrgs.br; msp@ufrgs.br.

(Recebido em agosto de 2004. Aceito para publicação em abril de 2005).

Est. econ., São Paulo, 35(4): 657-685, out-dez 2005 